\title{
Customers' contamination concerns: An integrative framework and future prospects for service management
}

\author{
Simon HAZÉE \\ Université catholique de Louvain, LouRIM, CCMS \\ Chaussée de Binche 151, 7000 Mons, Belgium \\ simon.hazee@uclouvain.be \\ (Corresponding author)
}

Yves VAN VAERENBERGH

KU Leuven

Warmoesberg 26, 1000 Brussels, Belgium

yves.vanvaerenbergh@kuleuven.be

(Both authors contributed equally to this paper)

Paper accepted for publication in Journal of Service Management

(DOI : 10.1108/JOSM-04-2020-0129)

Keywords: Contamination, Contagion, Disease avoidance, Service management, Coronavirus, Covid-19

Paper type: Literature review

Disclaimer : This paper was deposited under the Creative Commons Attribution Noncommercial International Licence 4.0 (CC BY-NC 4.0). 


\title{
Customers' contamination concerns: An integrative framework and future prospects for service management
}

\begin{abstract}
Purpose: Customers might become concerned about getting contaminated and adapt their behavior accordingly, which is of critical concern for service managers. The purpose of this paper is threefold. First, this paper synthesizes the extant body of research within psychology and marketing into an integrative framework that helps understand the current state of knowledge on contamination. Second, this review summarizes evidence-based managerial recommendations on how to deal with customers' contamination concerns. Third, this paper provides guidance for future research by proposing several ways in which those concerns might influence service management.
\end{abstract}

Design/methodology/approach: This paper conducts an integrative literature review of over 30 years of psychology and marketing research on contamination concerns.

Findings: The paper reviews physical and meta-physical contagion models, the situational cues that may activate customers' contamination concerns, the psychological mechanisms that underlie the relationship between contamination and customer outcomes, and the individual characteristics that influence customer sensitivity to contamination cues. Moreover, this review identifies actions that service managers can take to prevent customers' contamination concerns. Finally, still much has to be learned about how organizations should deal with fear of contamination by the time a next pandemic breaks out.

Originality/value: This paper develops an integrative framework that serves as a structured knowledge map onto the contamination phenomenon and paves the way for future service research. 
Keywords: Contamination, Contagion, Disease avoidance, Service management, Coronavirus, Covid-19

Paper type: Literature review 


\section{Introduction}

Disease avoidance is key to survival. Humans have developed a behavioral immune system that drives them to change their behavior in response to contamination cues suggesting the presence of pathogens (Curtis et al., 2011). Customers can hardly switch their contamination concerns off once activated (Rozin and Nemeroff, 1990), which is of critical concern for managers. Contamination concerns may influence customer experience (Klaus and Manthiou, in press) as well as customer perceptions and behavior such as seeking clean, familiar, or new products and services (Griskevicius and Kendrick, 2013). Delivering a relevant and reliable customer experience is critical to overall business performance (De Keyser et al., 2020). In this context, service researchers and practitioners need a clear understanding of (i) what triggers customers' contamination concerns, (ii) how the latter influence their experience, perceptions and behavior, (iii) what individual characteristics influence sensitivity to contamination cues, and perhaps most importantly, (iv) what managers can do to prevent customers' contamination concerns and deliver a reliable customer experience.

Research on customers' contamination concerns, however, occurred in various disciplines and used a variety of approaches. This diversity makes it difficult for researchers and practitioners to see the forest through the trees. Moreover, the Covid-19 outbreak revealed several deficiencies in the understanding of customers' contamination concerns. The first aim of this paper is to synthesize current knowledge on customers' contamination concerns and integrate this knowledge into an overall framework (see Figure 1) $)^{1}$. This integrative review is

\footnotetext{
${ }^{1}$ In line with similar previous studies (e.g., McColl-Kennedy et al., 2017), an ancestral or cross-reference search was conducted to identify relevant articles. In particular, citations of early and prominent (i.e., the most cited) articles on contamination in the marketing (e.g., Argo et al., 2006) and psychology literature (e.g., Rozin et al., 1986) were searched. To be retained, articles had to meet four main criteria. First, articles had to be published in a peer-reviewed journal. Second, given the topic of this Special Section, the research focus had to be on negative contamination stemming from a physical contagion model. Third, articles had to empirically examine contamination and its effects, thereby excluding conceptual articles and literature reviews. Fourth, articles had to have a defined sample and methodology. In the next step, the selected articles were critically analyzed, with a specific focus on the main variables and relationships examined in the study. This analysis generated the new integrative framework (Figure 1) that is presented and discussed next.
} 
explicitly focused on providing researchers and practitioners who are less familiar with contamination research with a state-of-the-art in this area. In addition, practitioners are in need of recommendations on how to deal with customers' contamination concerns. The second aim of this paper is to present evidence-based recommendations on how to manage these concerns. The third objective is to highlight remaining gaps in current knowledge that need to be addressed in order to prepare managers for a potentially recurring outbreak of Covid-19 (Kissler et al., 2020) or any other future pandemic.

[Insert FIGURE 1 around here]

\section{What we know about customers' contamination concerns}

\subsection{Theoretical background}

The laws of sympathetic magic (Frazer [1890] 1959; Tylor [1871] 1974) summarize several universal principles of thinking, beliefs and practices that would explain how the world works. Among them, the law of contagion holds that "people, objects, and so forth that come into contact with each other may influence each other through the transfer of some or all of their properties" (Nemeroff and Rozin 1994, p. 159). This transfer may be permanent and continue even after contact has occurred (Hajmadi et al., 2004). For instance, anthropological research shows the Hua tribe members in New Guinea believe that a person's essence resides in the garments that s/he has worn (Meigs, 1984). People can have both negative and positive responses to contagion (Rozin et al., 1986, 1989), yet they result from different models.

Researchers proposed two contagion models, namely meta-physical and physical models. Non-physical models rely on a meta-physical connection or 'link' connecting the source to the target (Morales et al., 2018). In this case, contagion involves magical beliefs of symbolic interactions or transfers of spiritual essence (Nemeroff and Rozin, 2018). Positive contamination typically results from a meta-physical model. People want to be associated 
with objects that are (meta-physically) connected to someone about whom they have positive feelings, such as attractive persons (Argo et al., 2008) or celebrities (Newman et al., 2011). Negative contamination may also result from a meta-physical model (e.g., a sweater worn by Hitler; Nemeroff and Rozin 1994) but is usually triggered by physical contagion models.

Physical contagion models include a germ model, defined as "contagion being carried by a living invisible entity, or micro-organism or germ" (Nemerrof and Rozin, 1994, p. 172), and a residue model, which posits that contamination is contingent upon sensible, perceptible residues or traces such as odor or body heat. Physical contagion models require physical contacts between objects/persons. For example, customers are also less likely to use accessbased services (e.g., car-sharing) or collaborative consumption (e.g., Airbnb) as they fear being contaminated by germs left on the shared objects by previous users (Hazée et al., 2017, 2020b). Customer reactions to the Covid-19 pandemic (Wu et al., 2020) mainly result from a (negative) physical contagion model. Hence, given the theme of this Special Section, this paper focuses on negative contamination stemming from a physical contagion model.

\subsection{Negative function of contamination and underlying mechanisms}

In negative contamination, the pathogenic properties that were transferred from the source to the target typically elicit perceptions of physical risks, such as health and safety concerns (e.g., White et al., 2016), or feelings of fear (e.g., Galoni et al., 2020). Fear of contamination can be complex, persistent and powerful, and therefore difficult to manage (Rachman, 2004). The feeling of contamination (i.e., the feeling of having been "polluted" or infected in some ways) may also trigger disgust (Schaller and Park, 2011). Disgust relates to feelings of revulsion and activates defensive reactions to avoid potential contaminants (see Rozin et al. [2008] for a review). 
Contamination concerns lead to a variety of outcomes. Interpersonal outcomes of contamination concerns involve becoming more socially avoidant, more introverted and less tolerant of strangers (e.g., Duncan et al., 2009; Mortensen et al., 2010; Schaller and Murray, 2008). Product- or brand-related outcomes involve a devaluation of contaminated brands and products. Contamination concerns affect attitudes toward the product or brand, purchase intentions and willingness to pay (e.g., Bezançon et al., 2019; Meng and Leary, 2019; White et al., 2016). Contamination concerns also influence customer choice. People high in contamination concerns prefer service providers that emphasize safety, are less likely to use air travel services, and prefer nearby travel destinations, among others (e.g., Griskevicius and Kendrick, 2013; Hamamura and Park, 2010). The large set of undesirable outcomes underscores the importance of identifying the cues that activate customers' contamination concerns.

\subsection{Situational cues that trigger customers' contamination concerns}

While contamination is ubiquitous, customers usually do not pay special attention to negative contagion. For example, in a hotel, the bed, toilet, and shower have all been touched by others. In a retail store, the shopping cart, payment terminal, and self-scanning device were

touched by other customers. As Nemeroff and Rozin (2018) recognize, "uncontrolled negative contagion sensitivity would be crippling” (p. 617). Against this backdrop, Morales et al. (2018) propose to amend the law of contagion and suggest that physical contact does not always lead to contamination concerns. Customers' contagion beliefs are dormant by nature and are activated by situational cues, categorized as 'social', 'environmental', 'brand-related' and 'product-related' cues.

Social-related contamination cues mainly relate to the number of sources believed to have come into contact with the target and the characteristics and/or nature of the contact 
source. Customers' evaluations and willingness to pay are lower when they believe that many people have touched a product (Argo et al., 2006). These reactions typically occur when customers believe that another unknown shopper, an unattractive salesperson, or a dissimilar person (e.g., opposite gender, foreign ethnic group or any other outgroup member) has previously come into contact with a specific object (Faulkner et al., 2004; Olatunji et al., 2014; Reicher et al., 2016; Taylor, 2007).

Environmental cues such as organization of the contact location, servicescape cleanliness, and sanitary crises have also been found to trigger customers' contamination concerns. First, in a retail setting, purchase likelihood and customer preferences for ingested products decrease when they are positioned on disorganized shelf displays (Castro et al., 2013). This disorganization signals that other shoppers have touched the products. Second, clean and visually appealing facilities are less likely to activate customers' contamination concerns (Barber and Scarcelli, 2010; Vilnai-Yavetz and Gilboa, 2010). Finally, sanitary crises such as the global Covid-19 pandemic trigger contamination concerns, which in turn increase panic buying or hoarding, the number of contactless payments and online transactions (Addo et al., 2020; Kirk and Rifkin, 2020).

Brand-related cues, such as brand communications (e.g., advertising, promotions), may raise contamination concerns. Hazée et al. (2019) show that when firms vividly highlight physical contacts between products and users in advertisements, customers whose contagion beliefs are activated are less likely to use access-based services. Brand equity can also influence the dormant nature of contagion beliefs. Customers are less likely to exhibit negative contamination concerns about access-based services with high (versus low) brand equity, as they believe the previous users who have touched the objects are more competent (Hazée et al., 2019). 
Product-related contamination cues include product location, product-body proximity, product scarcity and product packaging. People perceive objects located near contamination sources (e.g., dressing room or another disgusting product) as less desirable than those far away (Argo et al. 2006; Kim and Kim, 2011; Morales and Fitzsimons, 2007). Customers' contamination concerns also increase when products are used in close contact with their body (Hazée et al., 2019). Contamination concerns appear particularly salient for products that are ingested (Rozin et al., 1986). Product scarcity may also serve as a contamination cue. For example, Castro et al. (2013) find that for ingested products, a limited number of products on display reduces purchase likelihood. Finally, even superficial imperfections in the form of packaging damage (e.g., a ripped label) can activate customers' contamination concerns (White et al., 2016). People get rid of worn, dirty (versus clean) money bills quicker as they are concerned about potential contamination from others (Di Muro and Noseworthy, 2013).

Important to note, however, is that customers may create rules or frame information differently depending on the situation (Rozin and Nemeroff, 1990). Customers would be less likely to exhibit negative contagion beliefs in certain contexts, even when specific contamination cues are salient. For example, customers may have different ideas about the level of cleanliness in a fast food versus fancy restaurant. Understanding customer expectations and individual sensitivity to contamination cues is therefore crucial for service managers.

\subsection{Individual sensitivity to contamination cues}

Individual characteristics influence sensitivity to contamination cues. Research in psychology shows that individual differences such as disgust sensitivity (e.g., Olatunji et al., 2007), residue sensitivity (e.g., Kapitan and Bhargave, 2013), one's preferred internal system processing (rational vs. experiential; e.g., Kramer and Block, 2004), and personality traits 
(e.g., Haidt et al., 1994) affect the activation of contamination concerns. For instance, contamination sensitivity is positively related to neuroticism (Druschel and Sherman, 1999) but negatively related to openness (e.g., Olatunji et al., 2008) and agreeableness (e.g., Tybur et al., 2009).

Contamination-related responses also depend on demographic characteristics. Women are more likely to experience disgust feelings than men (e.g., Curtis et al., 2004; Olatunji et al., 2008). Pregnant women display higher levels of disgust sensitivity, particularly in the first trimester of their pregnancy (Fessler et al., 2004). Older people also experience less disgust feelings when confronted with contamination cues (Curtis et al., 2004). Researchers suggest an evolutionary explanation for these differences (see Huang et al. [2017a] for a review).

Finally, while the law of contagion suggests that individual customer reactions to contamination cues appear universal (Curtis et al., 2004), researchers suggest that pathogen prevalence might explain why cultures differ (Schaller and Park, 2011). Countries with high levels of pathogen prevalence are more likely to be collectivistic than individualistic. Behavioral manifestations of collectivism, such as conformity and ethnocentrism, help reduce the spread of pathogens, which is particularly relevant in regions with high pathogen prevalence (Fincher et al., 2008).

\section{How to get prepared for recurring Covid-19 outbreaks or future pandemics?}

As Kabadayi et al. (2020) note, the widespread impact of the outbreak of Covid-19 represents a service mega-disruption that most organizations were unprepared to handle. Some markets have collapsed completely (e.g., tourism), have shifted their business model (e.g., restaurants offering delivery), or have witnessed significant increases on consumer demand and faced problems with supply (e.g., online retail, healthcare). While simply keeping operations running already presented a major challenge for most organizations (Kabadayi et al., 2020), dealing with customers' contamination concerns added an additional layer of complexity. 
This section first reviews the recommendations provided in prior literature on how to deal with customers' contamination concerns, which can be taken into account almost immediately by organizations. At the same time, the Covid-19 outbreak and this review reveal deficiencies in the current understanding of how to deal with customers' contamination concerns. These knowledge gaps require a concerted research effort from the service research community. As at the time of writing this paper the tail of the Covid-19 curve is being reached in many countries, researchers should aim to urgently provide insights into these deficiencies to help managers, policy makers and healthcare providers get prepared for recurring Covid-19 outbreaks (Kissler et al., 2020) or any other future pandemic.

\subsection{Key learnings for managers based on existing literature}

Given the difficulty to deactivate contamination concerns, managers should try to prevent such concerns from occurring in the first place. This review identifies three main interventions. First, customers high in contamination concerns place special value on cleanliness (Griskevicius and Kenrick, 2013). Consequently, physical cleaning actions (e.g., deodorizing, sterilizing) seem to be most effective at removing cues that would otherwise trigger contamination concerns (Huang et al., 2017a). As customers are willing to pay more for enhanced disinfection of the servicescape (Zemke et al., 2015), organizations might consider offering "complete disinfections" against price premiums to those customers with high disgust sensitivity (Olatunji et al., 2008).

Second, structural change actions may also serve as "purifying" actions. People seem to value actions aimed at changing the structure or physical appearance of contaminated objects. For example, Nemeroff and Rozin (1994) show individuals feel more positive about a specific object (e.g., sweater) that has been previously touched when its form is subsequently changed (e.g., sleeves being cut) or when it is transformed into another object (e.g., scarf). 
Third, the situational cues identified in this review (see Figure 1) can also be used to attenuate the activation of contamination concerns. For instance, managers can block customers' contamination concerns by increasing perceptions of familiarity and similarity with other product or service customers (i.e., social cues; e.g., Hazée et al., 2019; Huang et al., 2017b), or by keeping shelf displays organized (i.e., environmental cue; Castro et al., 2013). Organizations could identify all (controlled and non-controlled) touchpoints throughout the customer journey (De Keyser et al., 2020) and examine whether each of these touchpoints might serve as contamination cues, as subtle these cues may be, and improve the customer journey accordingly.

These proposed interventions may have different effects on feelings of disgust than they may do on fear of contamination (Oaten et al., 2009). For instance, cleaning actions may be effective in removing disgust-eliciting cues (e.g., offending smells) but may not necessarily reduce fear of contamination. Disgust is typically more manageable and hence transient than fear (Rachman, 2004). This observation may explain why most of prior research has so far focused on preventing rather than reducing contamination concerns, and why so many businesses still have difficulties in reassuring customers in this pandemic situation.

\subsection{Remaining business challenges identified during the Covid-19 outbreak}

Most of the literature on contamination focuses on understanding the psychological mechanisms underlying contamination and its impact on customer outcomes (e.g., attitudes, willingness to pay), typically in a retail setting. Even though retailing can be considered as a service industry (Willems et al., 2016), more research is necessary to fully understand contamination concerns in services, which service-related cues might trigger contamination 
concerns, which consequences emerge, and what service providers can do about it. Table 1 lists a set of remaining challenges that should be addressed in future research ${ }^{2}$.

[Insert TABLE 1 around here]

Some priorities transcend specific aspects of the integrated framework. For example, prior research mainly focused on customers' contamination concerns, yet employees may also have contamination concerns. Research might explore which situational cues (e.g., unattractive or murky customers) activate employees' contamination concerns, how these contamination concerns influence their well-being, performance and turnover, and how frontline employees can overcome the paradoxical situation of providing good quality services to customers while being concerned about contamination. More and more employees also refuse to attend the workplace due to contamination concerns and fear of their coworkers' (mis)behavior (Fortune, 2020). How should managers deal with this situation and enhance employee experience? At the same time, some service settings traditionally involve disgusting or contagious circumstances (e.g., nursing). Why are contamination concerns dormant in one setting and not in others, and why are employees willing to work in environment being surrounded by potential pathogens?

Second, more work is needed to provide managers with insights on how to improve their service design and communicate about these changes (e.g., Hazée et al., 2020a). One intuitive approach to dealing with a pandemic might be to use safety signals by adding small details to the service design (e.g., wipes and alcohol gels) and/or offering messages about cleaning frequency in the servicescape (Benoit and Bove, in press). Doing so might turn out to be a double-edged sword. These cues might reduce negative contagion effects for those customers

\footnotetext{
${ }^{2}$ For the sake of relevance, the recommendations for future research that are presented and discussed next are based on practitioner input. In particular, a manager from a large Western-European retailer (with over 30 years of experience in a variety of industries) read an earlier draft of this paper. Next, an online interview (duration: $1.5 \mathrm{~h}$ ) has been conducted to (1) discuss how the current insights would help him in understanding and managing customers' contamination concerns, and (2) outline which insights are lacking, yet absolutely necessary. The two authors participated in the interview and discussed the findings in a follow-up (online) meeting.
} 
and employees whose contamination concerns were already activated before entering the servicescape. However, these additions might also bring to the fore that the pathogens might be prevalent in this setting, otherwise cleaning materials might not have been necessary, and therefore activate contamination concerns among individuals whose contagion beliefs were dormant.

One way to deal with this trade-off is to build models predicting which customers and employees are more likely to have contamination concerns. Demographic and psychographic traits might serve as initial independent variables for these models and can be supplemented with external information such as government announcements or social media data in order to increase predictive accuracy (Holmlund et al., 2020). Once customers (and employees) with high contamination concerns are identified, organizations can adapt their service offering to this segment. For example, these customers might receive specific communication on how the servicescape is cleaned, without communicating this information in the servicescape itself. Similarly, customers who receive a parcel do not know where the courier has touched it. Organizations can develop boxes that signal where customers and employees can touch the box and only use this type of boxes for this segment.

Third, future research might examine how customers react to contamination-related service failures and how organizations can recover from such failures. Observations suggest customers are more likely to complain, with overall call volume to contact centers jumping over 1,000\% from normal levels during the Covid-19 pandemic (Pindrop, 2020). While research identified an extensive set of recovery tactics (Van Vaerenbergh et al., 2019), these recovery tactics are typically applicable on 'traditional' failures (e.g., a long waiting time). Customers can hardly switch their contamination concerns off once activated; contaminationrelated failures might thus require very different recovery tactics. Also, customers often expect organizations to react to other-customer failures (Baker and Kim, 2018). Do customer 
expectations about an organizational response to other-customer failures (e.g., another customer is not complying with social distancing measures) increase when contamination concerns are active? Or are customers more likely to take actions themselves when their personal physical risk increases?

From a theoretical perspective, the contamination lens also allows us to challenge aspects of established service theories. For example, emotional labor theory can be refined by incorporating contamination concerns. Is emotional labor different when suppressing disgust or contamination concerns than when suppressing frustration or anger? Do (and how) surface and deep acting work when employees experience disgust feelings? Another example is the attribution theory, which is typically used to explain customer reactions to service failures (Van Vaerenbergh et al., 2014). In the case of a global pandemic like Covid-19, customers might attribute failures to uncontrollable (i.e., the organization could not prevent a global pandemic) and unstable causes (i.e., the pandemic is unlikely to recur on a regular basis). However, the pandemic occurs at a global level (i.e., all organizations are affected); within this global scenery, several controllable and stable failures might occur. Does attribution theory work at multiple levels? Adopting the perspective of contamination might lead to refinements to existing service theories.

\section{Conclusion}

The Covid-19 outbreak has activated contamination concerns among many customers. This paper provides managers with knowledge into how contamination concerns change customer behavior. The global scale of the Covid-19 outbreak and the high probability of recurring pandemics make the activation of customer contamination concerns on a regular basis plausible. This review reveals that more insights into how organizations can manage customer contamination concerns are highly necessary. We sincerely hope that this paper will inspire 
academics to engage in research that helps organizations to overcome the challenges of dealing with customers' (and employee's) contamination concerns. 


\section{References}

Addo, P., Jiaming, F., Kulbo, N.B. and Liangqiang, L. (2020), “COVID-19: fear appeal favoring purchase behavior towards personal protective equipment", The Service Industries Journal, forthcoming.

Argo, J., Dahl, D. and Morales, A. (2008), "Positive consumer contagion: Responses to attractive others in a retail context", Journal of Marketing Research, Vol. 45 No. 6, pp. 690-701.

Argo, J., Dahl, D. and Morales, A. (2006), "Consumer contamination: How consumers react to products touched by others", Journal of Marketing, Vol. 70 No. 2, pp. 81-94.

Baker, M.A. \& Kim, K. (2018), “Other customer service failures: Emotions, impacts, and attributions," Journal of Hospitality and Tourism Research, Vol. 42 No. 7, pp. 10671085.

Barber, N. and Scarcelli, J. (2010), "Enhancing the assessment of tangible service quality through the creation of a cleanliness measurement scale", Managing Service Quality, Vol. 20 No. 1, pp. 70-88.

Barnes, D. C., Mesmer-Magnus, J., Scribner, L., Krallman, A., Guidice, R. (in press), "Customer delight during a crisis: Understanding delight through the lens of transformative service research", Journal of Service Management, forthcoming.

Benoit, S. and Bove, L. (in press), "Restrict, clean and protect: Signaling consumer safety during the pandemic and beyond", Journal of Service Management, forthcoming.

Bartsch, S., Weber, E., Büttgen, M. and Huber, A. (in press), "Leadership matters in crisisinduced digital transformation: How to lead service employees effectively during the COVID-19 pandemic", Journal of Service Management, forthcoming. 
Bezançon, M., Guiot, D. and Le Nagard, E. (2019), “The role of negative physical contagion in the online purchase of second-hand products", Recherche et Applications en Marketing, Vol. 34 No. 4, pp. 2-28.

Castro, I., Morales, A. and Nowlis, S. (2013), "The Influence of disorganized shelf displays and limited product quantity on consumer purchase", Journal of Marketing, Vol. 77 No. 4, pp. 118-133.

Curtis, V., Aunger, R. and Rabie, T. (2004), "Evidence that disgust evolved to protect from risk of disease", Proceedings of the Royal Society B: Biological Sciences, Vol. 271 No. 4, pp. 131-133.

Curtis, V., de Barra, M. and Aunger, R. (2011), "Disgust as an adaptive system for disease avoidance behavior", Philosophical Transactions of the Royal Society B: Biological Sciences, Vol. 366 No. 1563, pp. 389-401.

De Keyser, A., Verleye, K., Lemon, K., Keiningham, T. and Klaus, P. (2020), “Moving the customer experience field forward: Introducing the touchpoints, context, qualities (TCQ) nomenclature", Journal of Service Research, forthcoming.

Di Muro, F. and Noseworthy, T. (2013), “Money isn't everything, but it helps if it doesn't look used: How the physical appearance of money influences spending”, Journal of Consumer Research, Vol. 39 No. 6, pp. 1330-1342.

Druschel, B. and Sherman, M. (1999), "Disgust sensitivity as a function of the Big Five and gender", Personality and Individual Differences, Vol. 26 No. 4, pp. 739-748.

Duncan, L., Schaller, M. and Park, J. (2009), "Perceived vulnerability to disease: Development and validation of a 15-item self-report instrument”, Personality and Individual Differences, Vol. 47 No. 6, pp. 541-546. 
Faulkner, J., Schaller, M., Park, J. and Duncan, L. (2004), “Evolved disease-avoidance mechanisms and contemporary xenophobic attitudes", Group Processes and Intergroup Relations, Vol. 7 No. 4, pp. 333-353.

Fessler, D.M.T., Eng, S.J. and Navarrete, C.D. (2004), "Elevated disgust sensitivity in the first trimester of pregnancy: Evidence supporting the compensatory prophylaxis hypothesis", Evolution and Human Behavior, Vol. 26 No. 4, pp. 344-351.

Fincher, C.L., Thornhill, R., Murray, D.R. and Schaller, M. (2008), "Pathogen prevalence predicts cross-cultural variability in individualism/collectivism", Proceedings of the Royal Society B: Biological Sciences, Vol. 275 No. 1640, pp. 1279-1285.

Finsterwalder, J., and Kuppelwieser, V. G. (in press), "Equilibrating resources and challenges during crises: A framework for service ecosystem wellbeing", Journal of Service Management, forthcoming.

Fortune (2020), "What do workers fear most about going back to the office? Each other", available at https://fortune.com/2020/05/26/going-back-to-work-employee-health-reopeneconomy-coronavirus/ (accessed 9 June 2020)

Frazer, J. ([1890] 1959), The New Golden Bough: A Study in Magic and Religion, Abridged ed., T. H. Gaster ed., Macmillan, New York.

Galoni, C., Carpenter, G. and Rao, H. (2020), “Afraid and disgusted: Consumer choices under the threat of contagious disease", Journal of Consumer Research, forthcoming.

Griskevicius, V. and Kenrick, D. (2013), “Fundamental motives: How evolutionary needs influence consumer behavior", Journal of Consumer Psychology, Vol. 23 No. 3, pp. 372386.

Haidt, J., McCauley, C. and Rozin, P. (1994), “Individual differences in sensitivity to disgust: A scale sampling seven domains of disgust elicitors", Personality and Individual Differences, Vol. 16 No. 5, pp. 701-713. 
Hajmadi, A., Rozin, P. and Siegal, M. (2004), “Once in contact, always in contact: Contagious essence and conceptions of purification in American and Hindu Indian children”, Developmental Psychology, Vol. 40 No. 4, pp. 467-476.

Hamamura, T. and Park, J.H. (2010), "Regional differences in pathogen prevalence and defensive reactions to the "Swine flu" outbreak among East Asians and Westerners", Evolutionary Psychology, Vol. 8 No. 3, pp. 506-515.

Hatfield, Elaine, John T. Cacioppo, and Richard L. Rapson (1994). Emotional Contagion, Cambridge, UK: Cambridge University Press.

Hazée, S., Delcourt, C. and Van Vaerenbergh, Y. (2017), "Burdens of access: Understanding customer barriers and barrier-attenuating practices in access-based services", Journal of Service Research, Vol. 20 No. 4, pp. 441-456.

Hazée, S., Van Vaerenbergh, Y., Delcourt, S., and Kabadyi, S. (2020a), "Risk management in sharing-based product service systems: The role of service delivery system design," International Journal of Operations \& Production Management, forthcoming.

Hazée, S., Van Vaerenbergh, Y., Delcourt, C. and Warlop, L. (2019), "Sharing a car? Yuks, no! An investigation of consumer contamination concerns in access-based services", Journal of Service Research, Vol. 22 No. 3, pp. 256-271.

Hazée, S., Zwienenberg, T.J., Van Vaerenbergh, Y., Faseur, T., Vandenberghe, A. and Keutgens, O. (2020b), "Why customers and peer service providers do not participate in collaborative consumption", Journal of Service Management, forthcoming.

Heinonen, K. and Strandvik, T. (in press), "Reframing service innovation: COVID-19 as catalyst for imposed service innovation", Journal of Service Management, forthcoming.

Henkel, A., Caic, M., Blaurock, M., Okan, M. (in press), "Robotic transformative service research: deploying social robots for consumer well-being during Covid-19 and beyond", Journal of Service Management, forthcoming. 
Holmlund, M., Van Vaerenbergh, Y., Ciuchita, R., Ravald, A., Sarantopoulos, P., Villaroel Ordenes, F., and Zaki, M. (2020), "Customer experience management in the age of big data analytics: A strategic framework," Journal of Business Research, forthcoming.

Huang, J., Ackerman, J. and Newman, G. (2017a), “Catching (up with) magical contagion: A review of contagion effects in consumer contexts", Journal of the Association for Consumer Research, Vol. 2 No. 4, pp. 430-443.

Huang, J., Ackerman, J. and Sedlovskaya, A. (2017b), “(De)contaminating product preferences: A multi-method investigation into pathogen threat's influence on used product preferences”, Journal of Experimental Social Psychology, Vol. 70, pp. 143-152.

Kabadayi, S., O’Connor, G.E., and Tuzovic, S. (2020), "Viewpoint: The impact of coronavirus on service ecosystems as service mega-disruptions," Journal of Services Marketing, forthcoming.

Kapitan, S. and Bhargave, R. (2013), "Navigating residue sensitivity in the used goods marketplace", Psychology and Marketing, Vol. 30 No. 4, pp. 305-317.

Kim, L. and Kim, N. (2011), “A proximity effect in adults' contamination intuitions”, Judgment and Decision Making, Vol. 6 No. 3, pp. 222-229.

Kissler, S.M., Tedijanto, C., Goldstein, E., Grad, Y.H. and Lipsitch, M. (2020), “Projecting the transmission dynamics of SARS-CoV-2 through the postpandemic period", Science, forthcoming.

Kirk, C. and Rifkin, L.S. (2020), "I'll trade you diamonds for toilet paper: Consumer reacting, coping and adapting behaviors in the COVID-19 pandemic", Journal of Business Research, forthcoming.

Klaus, Ph. and Manthiou, K. (in press), “Applying the EEE Customer Mindset in Luxury: Reevaluating Customer Experience Research and Practice During and After Corona”, Journal of Service Management, forthcoming. 
Kramer, T. and Block, L. (2011), "Nonconscious effects of peculiar beliefs on consumer psychology and choice”, Journal of Consumer Psychology, Vol. 21 No. 1, pp. 101-111.

McColl-Kennedy, J.R., Snyder, H., Elg, M., Witell, L., Helkkula, A., Hogan, S.J. and Anderson, L. (2017), “The changing role of the health care customer: Review, synthesis and research agenda", Journal of Service Management, Vol. 28 No. 1, pp. 2-33.

Meigs, A. (1984), Food, Sex, and Pollution: A New Guinea Religion, Rutgers University Press, New Brunswick, NJ.

Meng, M. and Leary, R. (2019), “It might be ethical, but I won't buy it: Perceived contamination of, and disgust towards, clothing made from recycled plastic bottles", Psychology \& Marketing, forthcoming.

Morales, A., Dahl, D. and Argo, J. (2018), “Amending the Law of contagion: A general theory of property transference", Journal of the Association of Consumer Research, Vol. 3 No. 4, pp. 555-565.

Morales, A. and Fitzsimons, G. (2007), "Product contagion: Changing consumer evaluations through physical contact with 'disgusting' products", Journal of Marketing Research, Vol. 44 No. 2, pp. 272-283.

Mortensen, C., Becker, D., Ackerman, J., Neuberg, S. and Kenrick, D. (2010), "Infection breeds reticence: The effects of disease salience on self-perceptions of personality and behavioral avoidance tendencies”, Psychological Science, Vol. 21 No. 3, pp. 440-447. Nemeroff, C. and Rozin, P. (1994), "The contagion concept in adult thinking in the United States: Transmission of germs and of interpersonal influence”, Ethos, Vol. 22 No. 2, pp. 158-186.

Nemeroff, C. and Rozin, P. (2018), "Back in touch with contagion: Some essential issue”, Journal of the Association for Consumer Research, Vol. 3 No. 4, pp. 612-624. 
Newman, G., Diesendruck, G. and Bloom, P. (2011), "Celebrity contagion and the value of objects", Journal of Consumer Research, Vol. 38 No. 2, pp. 215-228.

Oaten, M., Stevenson, R. and Case, T. (2009), "Disgust as a disease-avoidance mechanism”, Psychological Bulletin, Vol. 135 No. 2, pp. 303-321.

Odekerken-Schröder, G., Mele, C., Russo Spena, T., Mahr, D., Ruggiero, A. (in press), "Mitigating loneliness with companion robots in the COVID-19 pandemic and beyond: An integrative framework and research agenda", Journal of Service Management, forthcoming.

Olatunji, B., Williams, N., Tolin, D., Sawchuck, C., Abramowitz, J., Lohr, J. and Elwood, L. (2007), “The disgust scale: Item analysis, factor structure, and suggestions for refinement", Psychological Assessment, Vol. 19 No. 3, pp. 281-297.

Olatunji, B., Tomarken, A. and Zhao M (2014), "Effects of exposure to stereotype cues on contamination aversion and avoidance in African Americans", Journal of Social and Clinical Psychology, Vol. 33, No. 3, pp. 229-249.

Olatunji, B., Haidt, J., McKay, D. and David, B. (2008), “Core, animal reminder, and contamination disgust: Three kinds of disgust with distinct personality, behavioral, physiological, and clinical correlates", Journal of Research in Personality, Vol. 42 No. 5, pp. 1243-1259.

Pindrop (2020), "Flash report: Five insights of COVID-19 in the contact center", available at https://www.pindrop.com/blog/flash-report-five-insights-of-covid-19-in-the-contactcenter/ (accessed 9 June 2020)

Rachman, S. (2004), "Fear of contamination", Behaviour Research and Therapy, Vol. 42 No. 11, pp. 1227-1255. 
Reicher, S., Templeton, A., Neville, F., Ferrari, L. and Drury, J. (2016), "Core disgust is attenuated by ingroup relations", Proceedings of the National Academy of Sciences (PNAS), Vol. 113 No. 10, pp. 2631-2635.

Rozin, P., Millman, L. and Nemeroff, C. (1986), "Operation of the Laws of sympathetic magic in disgust and other domains", Journal of Personality and Social Psychology, Vol. 50 No. 4, pp. 703-712.

Rozin, P., Nemeroff, C., Wane, M. and Sherrod, A. (1989), "Operation of the sympathetic magical Law of contagion in interpersonal attitudes among Americans", Bulletin of the Psychonomic Society, Vol. 27 No. 4, pp. 367-370.

Rozin, P., Fallon, A., Haidt, J. and McCauley, C. (2008), “Disgust”, in Handbook of Emotions, M. Lewis, J. M. Haviland-Jones and L. F. Barrett (Eds), Guilford Press, New York, pp. 757-776.

Rozin, P. and Nemeroff, C. (1990), “The laws of sympathetic magic: A psychological analysis of similarity and contagion”, in J. W. Stigler, R. A. Shweder, \& G. Herdt (Eds.), Cultural psychology: Essays on comparative human development, Cambridge University Press, pp. 205-232.

Schaller, M. and Murray, D. (2008), "Pathogens, personality, and culture: Disease prevalence predicts worldwide variability in sociosexuality, extraversion, and openness to experience”, Journal of Personality and Social Psychology, Vol. 95, No. 1, pp. 212-221. Schaller, M. and Park, J. (2011), "The behavioral immune system (and why it matters)”, Current Directions in Psychological Science, Vol. 20 No. 2, pp. 99-103.

Taylor, K. (2007), "Disgust is a factor in extreme prejudice”, British Journal of Social Psychology, Vol. 46 No. 3, pp. 597-617. 
Tuzovic, S. and Kabadayi, S. (in press), "The influence of social distancing on employee wellbeing: A conceptual framework and research agenda", Journal of Service Management, forthcoming.

Tybur, J., Lieberman, D. and Griskevicius, V. (2009), “Microbes, mating, and morality: Individual differences in three functional domains of disgust", Journal of Personality and Social Psychology, Vol. 97 No. 1, pp. 103-122.

Tylor, E. ([1871] 1974), Primitive Culture: Researches into the Development of Mythology, Philosophy, Religion, Art, and Custom, Gordon Press, New York.

Van Vaerenbergh, Y., Orsingher, C., Vermeir, I. and Larivière, B. (2014), “A meta-analysis of relationships linking service failure attributions to customer outcomes", Journal of Service Research, Vol. 17 No. 4, pp. 381-398.

Van Vaerenbergh, Y., Varga, D., De Keyser, A. and Orsingher, C. (2019), "The service recovery journey: Conceptualization, integration, and directions for future research", Journal of Service Research, Vol. 22 No. 2, pp. 103-119.

Vilnai-Yavetz, I. and Gilboa, S. (2010), "The effect of servicescape cleanliness on customer reactions", Services Marketing Quarterly, Vol. 31 No. 2, pp. 213-234.

White, K., Lin, L., Dahl, D. and Ritchie, R. (2016), "When do consumers avoid imperfections? Superficial packaging damage as a contamination cue", Journal of Marketing Research, Vol. 53 No. 1, pp. 110-123.

Willems, K., Leroi-Werelds, S. and Swinnen, G. (2016), “The impact of customer value types on customer outcomes for different retail formats", Journal of Service Management, Vol. 27 No. 4, pp. 591-628.

Wu, F., Zhao, S., Yu, B., Chen, Y.-M., Wang, W., Song, Z.-G., Hu, Y., Tao, Z.-W., Tian, J.H., Pei, Y.-Y., Yuan, M.-L., Zhang, Y.-L., Dai, F.-H., Liu, Y., Wang, Q.-M., Zheng, J.-J., 
Xu, L., Holmes, E. and Zhang, Y.-Z. (2020), “A new coronavirus associated with human respiratory disease in China", Nature, Vol. 579, pp. 265-269.

Zemke, D., Neal, J., Shoemaker, S. and Kirsch, K. (2015), "Hotel cleanliness: Will guests pay for enhanced disinfection?", International Journal of Contemporary Hospitality Management, Vol. 27 No. 4, pp. 690-710. 
The law of contagion holds that "people, objects, and so forth that come into contact with each other may influence each other through the transfer of some or all of their properties"

(Nemeroff and Rozin 1994, p. 159)

\begin{tabular}{|c|c|}
\hline Contagion model & \\
\hline $\begin{array}{l}\text { Physical contagion } \\
>\text { Germ, residues }\end{array}$ & $\begin{array}{l}\text { Meta-physical contagion } \\
>\text { Symbolic interaction, } \\
\text { spiritual essence }\end{array}$ \\
\hline
\end{tabular}

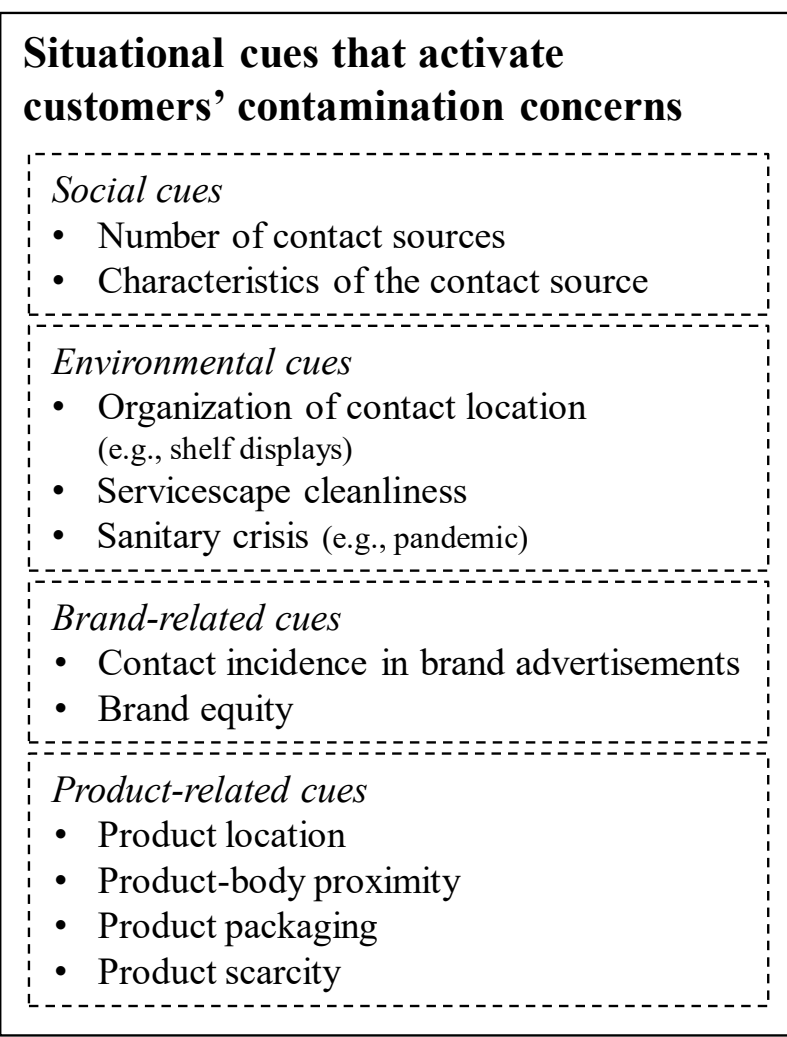

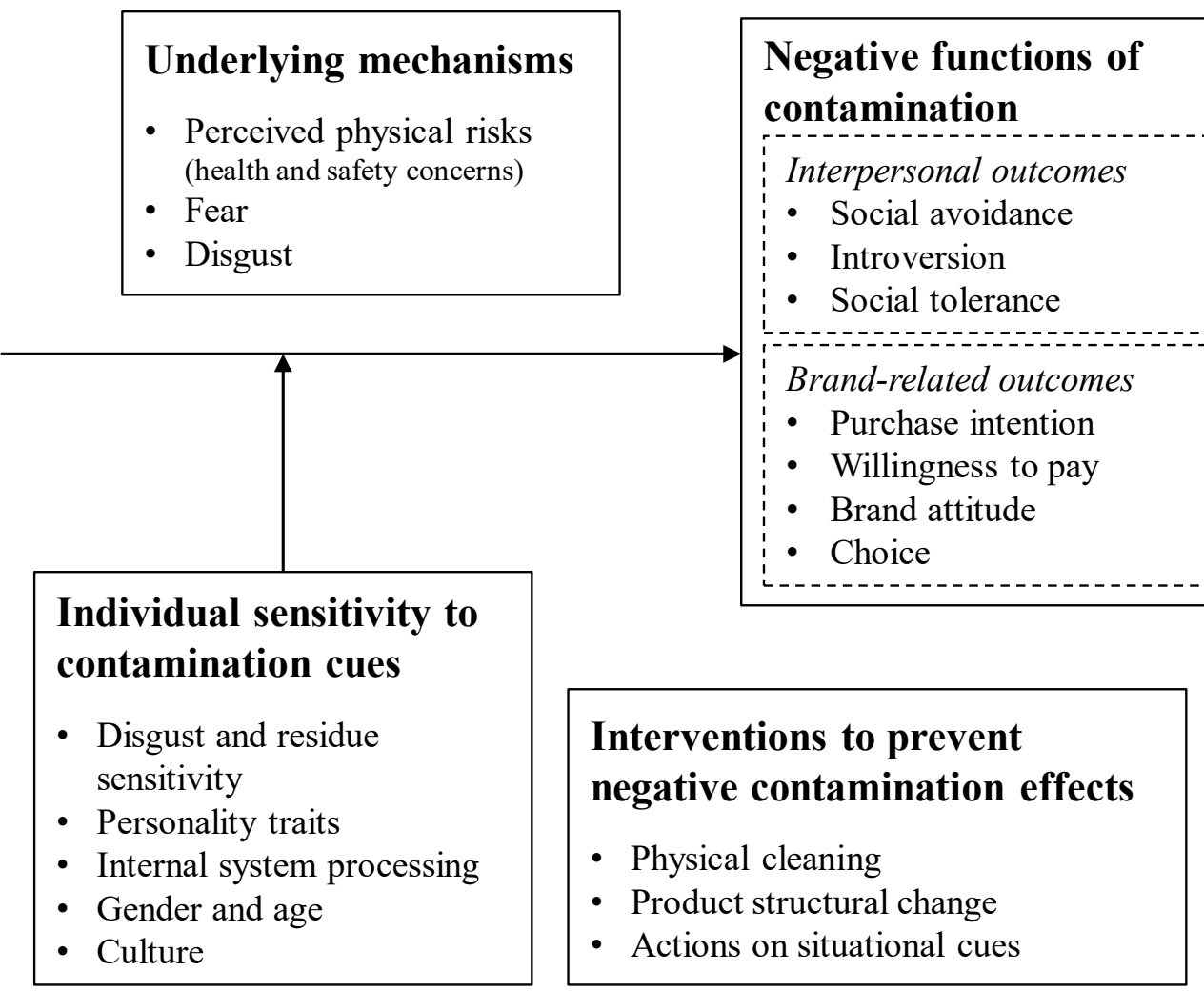




\section{Table 1: Opportunities for future service research}

\begin{tabular}{|c|c|}
\hline Research domain & Research questions \\
\hline $\begin{array}{l}\text { Understanding } \\
\text { consumer } \\
\text { contamination } \\
\text { concerns }\end{array}$ & $\begin{array}{l}\text { - How long are contamination concerns active in people's mind? } \\
\text { - } \quad \text { How salient are contamination cues in the aftermath of a global pandemic? How long } \\
\text { will customers be focused on contamination cues? } \\
\text { - } \quad \text { How will contamination concerns affect customer experience (e.g., Klaus and } \\
\text { Manthiou, in press)? } \\
\text { - Do individuals become more collectivistic as a result of having their contamination } \\
\text { concerns activated for a long period of time? } \\
\text { - How do contamination concerns affect employee experience? }\end{array}$ \\
\hline $\begin{array}{l}\text { Situational cues } \\
\text { that activate } \\
\text { contamination } \\
\text { concerns }\end{array}$ & $\begin{array}{l}\text { - Which additional cues in the servicescape trigger contamination concerns? } \\
\text { - Do people have less contamination concerns when products or services are produced } \\
\text { by a technology (e.g., a robot producing a pizza)? Do customers have more or less } \\
\text { contamination concerns when interacting with a technology (e.g., self-service) rather } \\
\text { than with a human employee? } \\
\text { - When do social or companion robots trigger customers' contamination concerns (e.g., } \\
\text { Henkel et al., in press; Odekerken-Schröder et al., in press)? } \\
\text { Which employee-related cues trigger contamination concerns? } \\
\text { - How do customer-to-customer interactions influence contamination concerns? When } \\
\text { do other customers trigger contamination concerns? } \\
\text { Can contamination concerns be activated when using online or digital channels (e.g. } \\
\text { videoconferencing)? }\end{array}$ \\
\hline
\end{tabular}

Negative functions - How can customers and employees effectively co-create value when at least one of of contamination the parties becomes socially avoidant during the interaction?

- How do contamination concerns affect customer perceptual, behavioral and financial outcomes (e.g., brand attachment, engagement, share of wallet, profitability)?

- Given that individuals with activated contamination concerns become socially avoidant, do customers prefer to use online channels (e.g. social media, email) rather than face-to-face channels along the customer journey (from information search to purchase and complaining)? If so, how can organizations manage to increase the social benefits of a customer relationship?

- How do contamination concerns affect customers' (e.g., Barnes et al., in press) and employees' well-being (e.g., Tuzovic and Kabadayi, in press), and ultimately service ecosystem well-being (e.g., Finsterwalder and Kuppelwieser, in press)?

- How could managers accurately predict negative consequences resulting from contamination and become more proactive?

Interventions to prevent or reduce negative contamination effects

As familiarity reduces contamination concerns, can organizations design services in
which customers always interact with the same employee?

- How can organizations design "touchless" services, in which the customer uses his or her own resources (e.g., a smartphone) to obtain the services from an employee or a technology (e.g., an ATM), and still create enjoyment?

- To what extent do customers' contamination concerns force organizations to innovate as an attempt to retain customers and reduce negative contamination effects (e.g., Heinonen and Strandvik, in press)?

- How can organizations recover from contamination-related failures? Would customers high in contamination concerns put more emphasis on distributive justice than on interactional justice?

- How should organizations deal with other customers as contamination cues? How can they properly inform a customer that he or she acts as a contamination cue to other customers?

- How should organizations help their workforce cope with contamination-related stressors? What leadership behaviors would work best in this situation (Bartsch et al., in press)? 


\begin{abstract}
AUTHOR BIO
Simon Hazée is an Assistant Professor of Marketing at UCLouvain (Belgium), attached to the LouRIM and CCMS. His research lies at the intersection of the fields of digital marketing and service management, and mainly focuses on sharing economy, customer experience management, and service recovery. Simon's work has appeared in the Journal of Service Research, International Journal of Operations and Production Management, Journal of Service Management, and Journal of Business Research, among others. He was the finalist of the SERVSIG Best Dissertation Award in 2018, and one of the highly commended recipients of the 2018 Emerald/EFMD Doctoral Research Awards. Simon serves on the editorial board of Journal of Service Theory and Practice. Simon Hazée is the corresponding author and can be contacted at: simon.hazee@uclouvain.be
\end{abstract}

Yves Van Vaerenbergh is an Associate Professor of Marketing at KU Leuven (Belgium). His research focuses mainly on service and customer experience management and seeks to better understand customer experience innovations, customer loyalty drivers, customer experience measurement, the role of employees, and customer dissatisfaction management, among others. His publications have appeared in Journal of the Academy of Marketing Science, Journal of Service Research, Journal of Retailing, and Academy of Management Perspectives, among others. He has received several best reviewer awards and best paper awards from service journals and serves on the editorial boards of the Journal of Service Research, Journal of Business Research, Journal of Service Management, and the Journal of Service Theory and Practice. 